\title{
'Proper Motions, Actions and Uses': Physiological Knowledge as the Only Means to Rational Politics in Restoration England
}

\author{
STEVE RIDGE*
}

Keywords: Walter Charleton; Physiology; Restoration; Politics

This article is drawn from a doctoral thesis called 'Governing Public Bodies: Reconsidering the Relationship Between Statecraft and Healthcare in England, 1650-1730', which considers two things: how certain categories of person, certain subjectivities, have been assembled through government in the name of health; and how the health of the individual has been understood to relate to that of the collective.

The particular writer focused on here is the physician and natural philosopher Walter Charleton (1620-1707). His publications are interesting because he presented his mechanical model of the human body as grounds for a practical project of interpreting what society was, and how it ought to have been organised. He coined the phrase 'physico-theology' in 1652 to describe his project of analysing ethical beliefs and moral motivations through studying the structure and functioning of human bodies. Researching his publications allows one to look in a new light at twenty-first-century understandings of the relationship between physiological expertise and arguments about certain individual behaviours being good or bad for collective society. Being thoroughly sensitive to the assumptions, aims, worries and associations of the seventeenth century serves as a distancing exercise, so that certain present healthcare-related objects and practices seem not quite so natural, desirable, obvious, stable and inevitable as one might take them to be. In other words, medical history can facilitate critical reflection upon the present.

This article forms part of an investigation of the production and government of certain categories of person and notions of the collective through contemporary medical and political practices. The aim is to generate a critical analysis of the notion of 'public health' that breaks with the naturalised present through a study that brings together questions of the governance of the body and of the commonwealth. 'Governance' here denotes the influencing, shaping and steering of action and belief toward certain ends through a series of discontinuous and often opportunistic alliances of actors. Importantly, I do not assume either a docile individual upon which governmental practices were imposed or an active individual that reacted to and appropriated regulation. Rather, I understand the actors as products of governmental practices. This is to argue that

(C) Steve Ridge, 2011.

\footnotetext{
* Steve Ridge, $\mathrm{PhD}$ student, The Wellcome Trust Centre for the History of Medicine at UCL, 183 Euston Road, London NW1 2BE, UK.

Email: steve.ridge@gmail.com
} 


\section{Steve Ridge}

certain versions of the human being, particular categories of person, have been brought into being partly by healthcare-related practices. This perspective is totally different from those of control or domination.

My thesis explores the balance between management of oneself and by others through attention to the history of bodily functions and economies. Direction of the affairs of state was only one of numerous definitions of governance in seventeenth-century England, others being the physical sense of the management of the limbs of the body and the moral sense of inculcating becoming conduct. It is important not to reduce government to the management of the state's resources if one is interested in models of government both within and without explicitly political reasoning and how these related to each other. This broader view of 'governance' reveals that it is not simply the case that physiology and medicine have been shaped by 'political forces'. The reverse has also been true. The words 'public' and 'health' have historically specific and mutable meanings. This can be demonstrated by looking at this critical time in English history, when contemporaries were disputing the nature of political power and the proper structure of society. Anatomists, physiologists and physicians were major voices in these debates.

In seventeenth-century English writing, the homology between the individual human body and the collective social body was not simply a literary device, but a shared set of important questions about the organisation of and transformations undergone by bodies and the kind of authority exercised within and upon them. Physiology and politics were inextricably linked in seventeenth-century England. Conclusions reached in one field of discourse were conventionally declared to be so in the other. Within serious debates about the legitimate grounds for rule, natural and civic bodies were compared in order to establish the divinely sanctioned means of regulating the members of a body and the proper relationships between them. The political turmoil in the middle of the century intensified such debate, as medical and political writers alike expressed an urgent need to establish consensual and peacemaking grounds for making true statements about the nature and purpose of bodies political and animal. The philosopher Thomas Hobbes (1588-1679) and his opponents aimed at restoring immortality to the body politic after the Civil War and regicide: both political and scientific reform during the Interregnum and Restoration were geared to envisioning and ensuring peace, prosperity and the perpetuity of organised communities. The more optimistic rival forms of medical knowledge in late seventeenth-century England sought to quell faction and fanaticism by attempting to form peaceable agreement that would serve as a model for society. The restored monarchy was seen as a fragile thing whose survival was dependent upon the ability of different groups to reach consensus. Natural philosophy was understood potentially to play an important role in this. The need for, and also the justification of, social cohesion was explicated within an experimental investigation of the human body. That is, models of the public body structured and functioning in accordance with natural laws were created and sustained by anatomists, physiologists and physicians. At stake was nothing less than the legitimacy of models of political rule and claims to know concomitant 'natural' processes of resource management. Here is an illustrative statement by Walter Charleton in his 1659 publication Natural History of Nutrition: 


\section{'Proper Motions, Actions and Uses'}

[Physiology is] A piece of Science, certainly, so far from being Unnecessary to a States-man, that I dare affirme, None, canever [sic] attain to any competent proficiency in the Mysteries of Stateprinciples, or the Art of Governing Men, who is not in some measure conversant in the Mysteries of Human Nature, as well those which concern the Constitution and Fabrique of the Body, as those which belong to the Inclinations and Passions of the Mind. And, the Reason hereof is obvious and plain; since the Maximes of sound Policy ought to be derived from the Lawes of Nature, at least by way of Analogie and Imitation: \& the best way to understand, how to preserve men in Societies, is to observe, How Nature at first produceth, and afterwards conserveth them in their Single Persons, or individual Beings. ${ }^{1}$

What was far from obvious was exactly what these 'laws of nature' were and how they could be known. Like almost all late seventeenth-century English natural philosophers, Charleton rejected the view that God had created the universe in accordance with reason - either in the sense of creating a rational order that embodied necessity or in the sense of an order existing independently from God. Typically, Charleton opposed the concept of necessary laws or natures - such as Aristotelian essences, causes or forms which inclined phenomena towards their ends by acting in accordance with eternal laws. He argued that this model of the Creation limited God's omnipotence and will.

For Charleton, the 'laws of nature' were experimentally demonstrable regularities that God could change at any time. The structure, function and behaviour of all knowable natural phenomena were totally contingent: moment by moment, God was guiding nature as He saw fit. He could change anything at any time. This meant that anatomical, physiological and medical knowledge was probable rather than certain. Charleton considered claims to certain knowledge and consequent efforts to propagate the 'one true faith' to have resulted in religious and civil wars. In his 1652 publication, The Darknes of Atheism Dispelled by the Light of Nature, he made the point that if religious beliefs were held to be probable because they were not demonstrable, then those he considered atheists and enthusiasts would have to relinquish their certainty and thus the threat of extreme scepticism was reduced. ${ }^{2}$ By removing the basis for certainty in religious beliefs he sought to render all the various competing theological schools of thought what he called mere 'opinion'. Charleton was by no means a radical latitudianarian. Rather, he assumed it reasonable to expect everyone to conform to a simplified and more liberal Anglicanism. His publications were an explicit response to civil war and expressed a concern to prevent attacks upon the authority of the Anglican Church. His books promulgated a view of secular and religious authority in keeping with the notion that the macrocosm of the universe and the microcosm of the body were contingent upon God's will.

Charlton maintained that moral philosophy was the art of moderating emotions and that this could not be achieved merely through knowledge of the dictates of prudence and the rules of virtue. Instead, he addressed the issue of governing belief and action through the explication of a physiologically informed theory of the passions. His proposed anatomical and medical means of understanding how society functioned involved

\footnotetext{
${ }^{1}$ Walter Charleton, Natural History of Nutrition (London: R. Daniel \& J. Redman, 1659), the Epistle Dedicatory. The book was also published the same year in Latin, as Oeconomia Animalis.
} 


\section{Steve Ridge}

an ethics wherein godly pleasure was to be regarded as the chief good, or the proper end of action. Following Gassendi, Charleton accepted the Epicurean notion of seeking pleasures and avoiding pains as the spring of human action but added Christian elements: a providential god, the immortality of the soul, and Heaven and Hell as the reward and punishment for good and evil behaviour. Charleton's 1674 publication, Natural History of the Passions, was largely based on a work from two years earlier, De Anima Brutorum, by the physician and natural philosopher Thomas Willis (1621-75). ${ }^{3}$ Willis understood the passions in material terms. For him, they were the physical results of the animal spirits responding to external stimuli within the brain and nervous system. He quoted Gassendi; 'the acquisition and loss of an habit stands in the Power of the Brain and Phantasie, [which is] a subject purely corporeal. ${ }^{4}$ Willis understood humans to be equipped with two souls, with the rational soul spiritual and superior, and the sensitive soul material and subordinate. This latter bodily soul was shared with animals and was located in the blood and in the brain. Charleton argued that physiological knowledge was politically useful because bodies could overwhelm minds. He attributed increased powers to the material sensitive soul.

Briefly, I have endeavoured to show that within iatromechanical discourse upon the governance of belief and action, physiological and moral reasoning became closely entwined. This stands in opposition to the argument made by some historians that English anatomy became desacralised in the period following the Civil War. For Charleton, where medicine and healthcare were truly important, was in providing statesmen with the wherewithal to rule rationally, the knowledge of how to suppress commotions in the body politic, and the proof of divine immanence and wisdom through the study of design. One wonders if the historical studies of conflicting and contested notions of the 'body politick' and 'animal œconomies' can potentially contribute toward more critical reflection upon the current relationship between politics and healthcare. I think so.

\section{Acknowledgements}

The research for the article was made possible by a studentship funding provided by The Wellcome Trust Centre for the History of Medicine at UCL.

\footnotetext{
${ }^{3}$ Walter Charleton, Natural History of the Passions (London: J. Magnes, 1674). Thomas Willis, De anima brutorum quae hominis vitalis ac sensitiva est, exercitationes duae (Oxford: Richard Davis, 1672). Willis's treatise was translated by Samuel
}

\author{
Pordage as Two Discourses Concerning the Soul of \\ Brutes Which is That of the Vital and Sensitive of \\ Man (London: Thomas Dring, Charles Harper and \\ John Leigh, 1683). \\ ${ }^{4}$ Willis, Two Discourses, ibid., 42.
}

